\title{
Contributions from the 9th International Conference on Gas in Marine Sediments, University of Bremen, 15-19 September 2008
}

\author{
Gerhard Bohrmann • Bo Barker Jørgensen
}

Received: 20 March 2010 /Accepted: 29 March 2010/Published online: 14 April 2010

(C) Springer-Verlag 2010

\begin{abstract}
Following the first International Conference on Gas in Marine Sediments in Edinburgh, UK (1990), another eight successful conferences have provided a continuous forum for scientists from a variety of disciplines, organisations and countries. The 9th meeting of the Shallow Gas Group was held in September 2008 in Bremen, a hanseatic city more than 1,200 years old in northern Germany. The Shallow Gas Group was joined for this conference by participants of the HERMES EU-funded project and by members of an industry-funded project. Volume $30(3 / 4)$ of Geo-Marine Letters is a double issue containing 25 selected papers from the 9th conference in Bremen, guest edited by G. Bohrmann and B.B. Jørgensen. The papers represent the broad spectrum of oral and poster contributions from the conference, covering a wide range of aspects of gas in marine sediments from many parts of the world. The next conference of the Shallow Gas Group is planned to be held in Listvyanka at Lake Baikal, Russia, in September 2010.
\end{abstract}

\section{Preamble}

Since the International Conference on Gas in Marine Sediments was launched in 1990, research into methane in marine

\footnotetext{
G. Bohrmann $(\bowtie)$

MARUM - Center for Marine Environmental Sciences and Department of Geosciences, University of Bremen, P.O. Box 330440, 28334 Bremen, Germany

e-mail: gbohrmann@marum.de

B. B. Jørgensen

Max Planck Institute for Marine Microbiology,

Celsiusstr. 1,

28359 Bremen, Germany

B. B. Jørgensen

Center for Geomicrobiology, Aarhus University,

8000 Aarhus, Denmark
}

environments has strongly advanced and seems to be still developing and broadening in disciplines. This trend is documented by a continuous increase in the number of publications, and special workshops and conferences. The International Conference on Gas in Marine Sediments covers all aspects of research related to methane in the aquatic environment. Major topics are:

- Formation of shallow gas in sediments and seepage at the seafloor

- Subsurface fluid flow, geochemical and thermal gradients

- Biological and biogeochemical processes in seep ecosystems

- Formation and destabilization of hydrates

- Diversity and functioning of methane seeps, bubble sites, pockmarks and mud volcanoes

- Imaging sub-seafloor gas and gas hydrate structures by seismic studies

- Regional studies on gas and gas hydrate distribution and quantification in sediments

- Seafloor emissions to the water column and gas quantification

- Methane-derived authigenic carbonates.

The 2008 Bremen conference on Gas in Marine Sediments followed eight successful conferences held in Edinburgh, UK (1990), Hirtshals, Denmark (1992), Texel, The Netherlands (1994), Varna, Bulgaria (1996), Bologna, Italy (1998), St. Petersburg, Russia (2000), Baku, Azerbaijan (2002) and Vigo, Spain (2005). Scientific papers from those meetings are to be found in several special issues of journals edited by Davis (1992), Jørgensen (1994), van Weering et al. (1997), Judd and Curzi (2002), Gramberg and Kontorovich (2002), Woodside et al. (2003, 2004) and García-Gil and Judd (2007). Volume 30 (3/4) of Geo-Marine Letters is a double issue containing 25 selected papers from the 9th 
conference in Bremen, guest edited by G. Bohrmann and B.B. Jørgensen

\section{The conference}

The Shallow Gas conference 2008 took place from 15 to 19 September at the University of Bremen. Sessions were held at the Geosciences building, the building of the Max Planck Institute for Marine Microbiology and the MARUM building, which are all located in close proximity on the campus of the university. Participants from academic, governmental and commercial institutions included about 141 scientists from 24 countries. During the 3 days of the main meeting (16-18 September), 65 oral presentations and 54 posters were presented in morning and afternoon sessions. The contributions covered all aspects of research related to methane in the ocean. Current knowledge and future programmes dealing with methane inventories and fluxes, and their role in the carbon cycle and relevance for biodiversity were discussed by an interdisciplinary group of scientists, mainly geologists, biologists, microbiologists, geophysicists, oceanographers and geochemists. As part of the International Conference, a special session on Methane as a driver of cold seep ecosystems and microbial habitats hosted by the 6th FP EU project HERMES Hot spot Ecosystem Research on Margins of European Seas was held on Thursday 18 September. The talks of that programme, focussing on the Mediterranean Sea, were complemented by four presentations of the West Nile Delta Project (WNDP), a project funded mainly by industry.

\section{Fieldtrips}

Two 1-day fieldtrips were organised at the beginning and end of the conference. On Monday 15 September, Joern Peckmann (MARUM, Bremen) guided the fieldtrip to the Harz Mountains, $200 \mathrm{~km}$ southeast of Bremen. The group first visited the type location where E. Kalkowsky coined the term stromatolite in 1908. The outcrop shows impressive stromatolitic structures in lacustrine sediments of the lower Triassic Buntsandstein (Fig. 1). They then viewed the Early Carboniferous seep site (Fig. 2) on top of the drowned Devonian Iberg atoll reef (Peckmann et al. 2001). The second fieldtrip on Friday 19 September, guided by Achim Wehrmann (Senckenberg Institute, Wilhelmshaven) and Christian Winter (MARUM, Bremen), was to Spiekeroog Island in the German Wadden Sea. Like all Frisian barrier islands, Spiekeroog is separated from the mainland by a tidal backbarrier basin which is completely inundated at high tide and largely exposed at low tide. After a ferry boat trip from the picturesque coastal village of Neuharlinger-

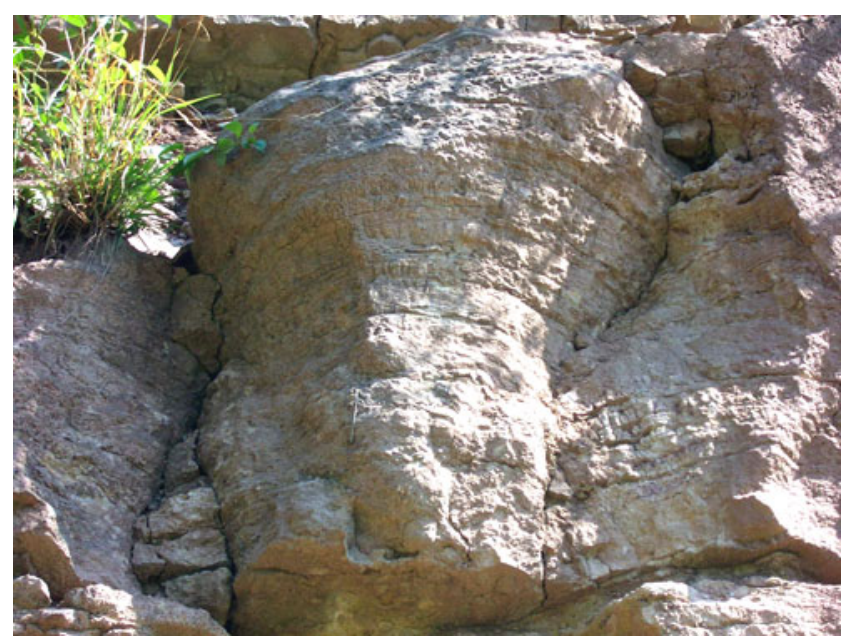

Fig. 1 Stromatolitic dome in red lacustrine sediments of the lower Triassic Buntsandstein at the type location where Kalkowsky (1908) coined the term stromatolite. The outcrop was visited by participants of the 9th International Conference on Gas in Marine Sediments, guided by Joern Peckmann (Photo J. Peckmann)

siel, the participants toured the island and viewed the main sedimentary environments of this highly dynamic tidal system (Fig. 3).

\section{Papers in this special issue}

Fluid and gas emissions escaping from the seabed are widespread worldwide, and a variety of seep types have been documented. Of all seep structures, mud volcanoes seem to be the most active seep sites, because of the rapid transport not only of gas and fluids but also of fluid- and gas-rich fine-grained sediments or mud. Thus, mud volca-

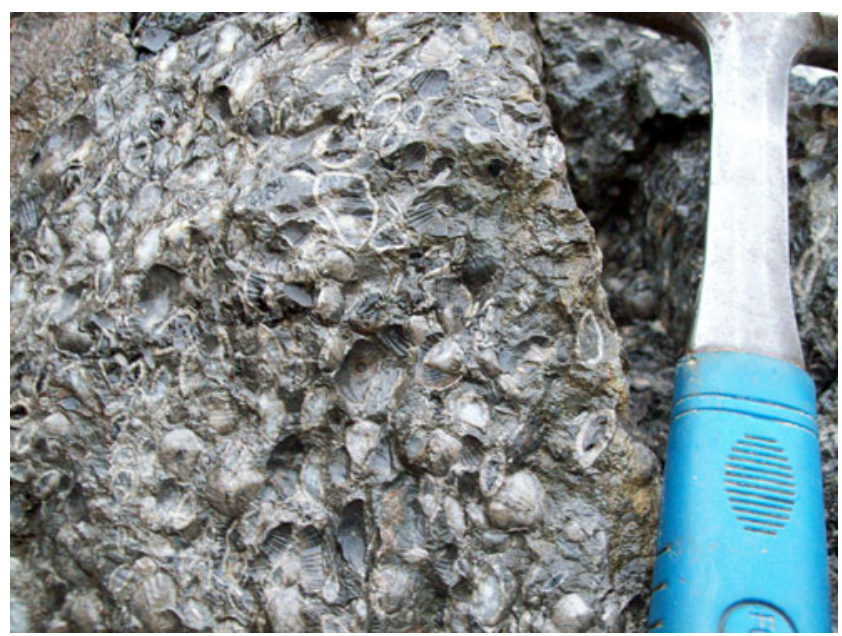

Fig. 2 Late Visean low-diversity seep fauna (mainly brachiopods) on top of a hydrocarbon seep, shown by Joern Peckmann during the fieldtrip to the Harz Mountains on Monday 15 September 2008 (Photo T. Himmler) 


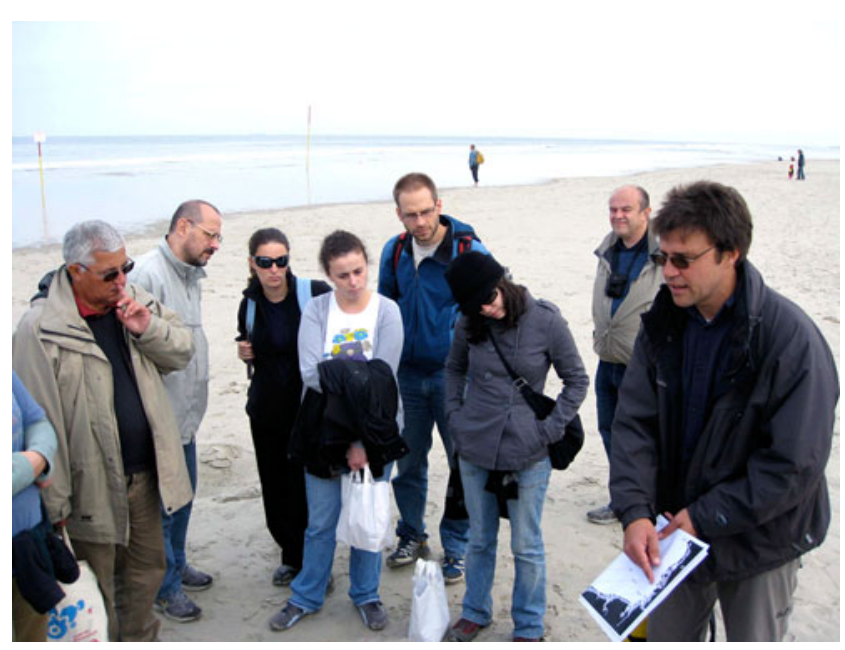

Fig. 3 Participants of the Shallow Gas Conference 2008 discussing sedimentary deposits at the beach of the Frisian island of Spiekeroog. Achim Wehrmann (right) and Christian Winter guided the fieldtrip on Friday 19 September 2008 (Photo T. Lorenson)

noes seem to have high flux rates of volatiles and, in the case of long-lived geological mud volcanic activity, the volcanoes form spectacular mounds in the submarine landscape. Mud volcanoes episodically experience violent eruptions of large amounts of mud and rock fragments mixed with gas and water, which produce the volcanoshaped structures. Between eruptions, quiescent stages occur when distinctly less material and volatiles ascend in the conduit to the surface of the volcano. In order to measure changes in the activity of mud volcanism, Foucher et al. performed high-definition seabed mapping surveys of the Håkon Mosby mud volcano (HMMV) in 2003 and again in 2006. The HMMV is a well-known, isolated mud volcano on the Southwest Barents Sea Slope at a water depth of 1,270 $\mathrm{m}$. Small but significant changes in surface morphology and fluid activity were documented by these authors, interpreted to represent a quiescent stage of mud volcanism. Since high-resolution follow-up measurements of distinct deep-sea geological features performed by ROV or AUV platforms are still very rare, this paper is a stimulating example of how progress in deep-sea technology heralds the science of the future. Rapid changes from dormant to active stages in mud volcanism were documented for the Giza and North Alex mud volcanoes on the upper slope of the western Nile deep-sea fan by Feseker et al. The multidisciplinary research group used several datasets including temperature measurements, pore water chemistry and geological observations to investigate the dynamics of the two mud volcanoes. Biostratigraphic dating of the mud breccias documented the deep sources of the mud (1,000-2,000 m). High temperatures reaching $70^{\circ} \mathrm{C}$ in the mud at the surface were explained by the rapid upward movement of gas-rich sediments in the conduits of the mud volcanoes. In contrast to the Giza and North Alex mud volcanoes, the Amsterdam mud volcano in the Anaximander Mountains of the eastern Mediterranean studied by Pape et al. is influenced by gas hydrate formation and destabilization processes. This submarine mountain region is currently undergoing tectonic deformation accompanied by active strike-slip faulting and mud volcanism. Although gas hydrates are known from several mud volcanoes of that region, the authors provide first evidence for gas hydrate structure sII in the Mediterranean. They used pressure coring for the quantification of light hydrocarbons and gas hydrates in the near-surface deposits of the Amsterdam mud volcano.

Crater-like pockmarks are widespread seabed structures commonly associated with seabed fluid flow. They are typically some meters to tens of meters deep and up to several $100 \mathrm{~m}$ in diameter. Because of their diverse morphology, size and character, pockmark formation seems to be influenced by a variety of mechanisms. Pockmarks are described from the Landes Plateau of the Bay of Biscay by Iglesias et al. They interpret these features to be formed by combined processes involving collapse, subsidence and sedimentary erosion of seabed sediments and escaping fluids, triggered by tectonic and fluid dynamic processes acting on the Landes Plateau in former times. An even more complex evolutionary history is suggested by Hjelstuen et al. for the pockmarks in the Nyegga region located at water depths of about $600-800 \mathrm{~m}$ on the continental margin of Norway. Inspection of newly collected swath bathymetric records and high-resolution seismic profiles indicated that active seepage is the main process of formation, as the depression features would otherwise have been filled by sediments. Pockmarks in the Gulf of Cádiz (Spain) are described by León et al. as one type in a whole suite of morphological fluid escape features. The pockmarks there often appear aligned along blind valleys and numerous deep-water channels which were formed as furrows by Mediterranean Outflow Water (MOW). The authors interpret the seabed fluid flow and the formation of pockmarks as an important process triggering erosion along channels by the warm and denser MOW.

Seabed fluid flow is often associated with free gas emission. Methane of microbial or thermogenic origin formed during sediment burial migrates upwards to the surface because of its buoyancy. Near-surface sediments hence contain methane and other light hydrocarbons shown by numerous sediment sampling and geophysical investigations. Distribution patterns of such light hydrocarbons are presented in the paper of Lavrenova and Kruglyakova for the Paleozoiskiy petroleum licence area of the central Sea of Azov. The patterns formed by light hydrocarbons clearly show the relationship between hydrocarbon anomalies and fault zones, which are active migration pathways 
for the gases. Based on acoustic studies of bottom sediment characteristics in Lake Kinneret, Ostrovsky and Tęowski identified likely relationships with changes in gas content. This lake in Israel, also known as the Sea of Galilee, was investigated by $120-\mathrm{kHz}$ single-beam echo-sounder profiles which were then calibrated with sedimentological characteristics including organic matter content and granulometry.

Within the gas hydrate stability field defined by temperature, pressure and various chemical parameters, natural gas in concentrations above solubility occurs as a solid gas hydrate component. Gas hydrate deposits are found worldwide in marine sediments, in permafrost areas where the permafrost thickness is greater than $100 \mathrm{~m}$, and in deposits of Lake Baikal. In oceanic sediments, gas hydrate occurs where bottom-water temperatures approach $0^{\circ} \mathrm{C}$ and water depths exceed about 300-350 m. The maximum lower limit of methane hydrate occurrence is determined by the geothermal gradient. Its position is well characterized by changes in physical properties showing an anomalous bottom-simulating reflector (BSR) on seismic profiles. In the paper by Vargas Cordero et al., detailed geophysical analyses of BSR structures offshore Chile show different concentrations of gas hydrates and free gas above and below the BSR along two profiles on the continental margin. Seismic data were also used by Crutchley et al. to document the influence of gas hydrates on erosion processes of Rock Garden, an uplifted accretionary ridge offshore of New Zealand. Based on their analyses, gas migration through the gas hydrate stability zone occurs on top of the ridge because of significant fluid overpressure, which leads to regional sediment erosion on the ridge crest. Numerical studies of gas hydrate systems are presented by Hauschildt et al. The authors used a two-dimensional numerical hydrate model to show how hydrate concentrations are affected by regions of low permeability which deflect the flow field in their vicinity. Two papers by Hachikubo et al. report analyses of actual gas hydrate samples cored from near-surface sediments offshore Sakhalin Island in the Sea of Okhotsk and in Lake Baikal. Stable isotope data of methane from the Sakhalin Island gas hydrates indicate that the methane was produced by microbial reduction of $\mathrm{CO}_{2}$. By contrast, that in gas hydrates from Lake Baikal deposits has different sources. In addition to six seep sites dominated by microbial methane, two seep locations are presented where higher hydrocarbons were documented and the carbon isotopes largely showed the influence of thermogenic methane. Hachikubo et al. propose mixed hydrates of structure I and structure II for some gas hydrate locations in Lake Baikal.

Marine hydrocarbon seeps occur along continental margins worldwide, representing focused sources of methane and traces of higher hydrocarbons fed to the ocean and the atmosphere. Hydrocarbon seeps have been the subject of multiple studies in recent decades, due to their potential importance as methane sources in the global methane budget and due to their interesting hydrocarbon-based biotic communities and carbonate structures.

One of the most thoroughly studied marine seep systems is the Coal Oil Point (COP) Seep Field off southern California, which is the subject of five papers in this special issue. The system is located over a producing hydrocarbon reservoir, and the underlying geology is therefore of particular interest. Leifer et al. combined sonar surveys of seep distributions with maps of the underlying geology to analyze the causes of the distribution pattern of the seepages. Seeps were found to follow the trends of major folds and faults in this tectonically stressed area, which probably comprises an even finer network of faults, joints and bedding planes which may further explain spatial seep distributions. Bubble streams of individual seeps vary with respect to bubble size and flux. Using a diver-operated video system, Leifer and Culling quantitatively recorded bubbles and were able to demonstrate systematic variations of their dimensions and flow velocity. Such variations were also generated by experimental bubble plumes in the laboratory. The source strength of the rather diffuse seep systems can be high, reaching 450 moles of $\mathrm{CH}_{4}$ per day in one selected COP area of only $200 \mathrm{~m}^{2}$, as reported by Kinnaman et al. Anaerobic oxidation of methane leads to extensive carbonate precipitation in shallow subsurface sediments, even where the emitted gas is rich in $\mathrm{CO}_{2}$ which should rather act to dissolve carbonates. The authors used data on the $\delta^{13} \mathrm{C}$ distribution pattern in carbonates to deduce how and where the carbonate precipitation took place. Mau et al. demonstrated that also the higher hydrocarbons ethane and propane are emitted from the seeps but that these are largely degraded in the water column. Only about $0.5 \%$ of $\mathrm{C} 2$ and $\mathrm{C} 3$ in the plume from the seep field is transferred to the atmosphere. During the ascent from the seabed to the sea surface, the gas composition of the bubbles changes. Thus, Clark et al. revealed that $\mathrm{CO}_{2}$ and $\mathrm{CH}_{4}$ are gradually lost and that $\mathrm{N}_{2}$ and $\mathrm{O}_{2}$ are taken up by exchange with the surrounding seawater. The composition of gas in bubbles at the sea surface therefore depends on the water depth of the seeps and the size of the rising gas bubbles.

Some very interesting gas seepage environments are found in the Black Sea and Lake Baikal. Malakhova et al. mapped and studied numerous seeps in shallow coastal waters and bays near Sevastopol. The water column is here often highly supersaturated with methane and is thus a local source of methane to the atmosphere. Recent acoustic surveys in Lake Baikal evaluated by Granin et al. revealed a large number of gas escapes, some occurring in shallow water associated with, for example, a large river delta, others in deep water sometimes associated with a distinct bottom-simulating reflector. A gas plume located near the deep St. Petersburg mud volcano was found to rise more than $950 \mathrm{~m}$ into the water column. 
In recent years, several areas of fluid and gas escape associated with gas hydrates have been discovered in the deep Lake Baikal. Around the Malenky Mud Volcano in the southern part of the lake, Zemskaya et al. report deep fluids rich in ions and methane rising to the sediment surface and strongly altering the pore water chemistry and microbiology of the surrounding sediment. Sulphate concentrations approached values typical of brackish water systems such as the Black Sea. Based on its $\delta^{13} \mathrm{C}$ signature, the methane was identified as being primarily of biogenic origin and, together with anaerobic oxidation of methane, methanogenesis was high in the sediment. This activity of methanogens is also indicated by the enrichment of ${ }^{13} \mathrm{C}$ in pore water DIC revealed by Krylov et al.

Gas and fluid escape structures are also found in the much shallower Baltic Sea where Pimenov et al. studied an interesting pockmark area in the Russian sector. Sediment biogeochemistry was dominated by the formation and cycling of biogenic methane which contributed up to $70 \%$ of the substrate for bacterial sulphate reduction in the sediment column. In spite of the effective retention of methane at the sulphate-methane transition, sufficient methane escaped to the water column to yield a detectable anomaly as high as $10 \mathrm{~m}$ above the bottom.

Authigenic carbonates formed around marine seep systems in the geological past have been found at a number of locations worldwide, such as the Apennine Mountains in Italy investigated by Conti et al. in this special issue. The carbonates found in the outcrops of these paleo-seeps have highly variable $\delta^{13} \mathrm{C}$ compositions, indicating different $\mathrm{C}$-sources, including the oxidation of methane, seawater DIC, or sedimentary organic matter. Some seep systems were apparently inhabited by large lucinid clams with chemosynthetic symbionts. The formation of the seep carbonates may partly have been controlled by the metabolism and bioirrigation of these clams. A very careful and detailed study of the petrographic features of another outcrop of seep carbonates and concretions found in the Tertiary Piedmont Basin, NW Italy, indicated unusual depositional and diagenetic conditions of formation. Martire et al. report that the peculiar properties of cements within cavities showed dolomite crystals floating within a cavity-filling calcite spar. Such non-gravitational fabrics of internal sediments plastering cavity walls suggest their original formation in association with gas hydrate which had presumably filled the space.
Acknowledgements We wish to express the gratitude of the Shallow Gas Group, and of all participants of the conference in Bremen to all members of the organising and scientific committees. Support was provided by the Max Planck Institute for Marine Microbiology, Bremen, and the Department of Geosciences and the Center for Marine Environmental Sciences (MARUM) at the University of Bremen. All sponsors who contributed to the success of the conference have been acknowledged elsewhere but we wish to specifically thank them again here for their support. We also thank the authors for their contributions, and the referees without whose help this special issue would not have been possible: Giovanni Aloisi, Nathan Bangs, Christian Berndt, Volker Brüchert, Warner Brückmann, Ingeborg Bussmann, Georg Delisle, Eric Deville, Gerald R. Dickens, Timothy Ferdelman, Jean-Paul Foucher, Soledad GarcíaGil, Aurélien Gay, Jens Greinert, Jan Harff, Michael Ivanov, Paul Johnson, Alan Judd, John Kessler, Arzhang Khalili, Ingo Klaucke, Achim Kopf, Nina Kukowski, Peter Linke, Tom Lorenson, Andreas Lückge, Dimitris Marinakis, Luca Martire, Douglas G. Masson, Tatiana Matveeva, Patrick Meister, Jürgen Mienert, Thomas Naehr, Thomas Pape, Charles K. Paull, Joern Peckmann, Constantine Perissoratis, Alban Ramette, Gregor Rehder, Carsten Schubert, Klaus Schwarzer, Alina Stadnitskaia, Erwin Suess, Barbara Teicher, Marta E. Torres, Anne Tréhu, Tina Treude, David Valentine and numerous anonymous reviewers.

\section{References}

Davis AM (ed) (1992) Methane in marine sediments. Cont Shelf Res 12(10):1075-1264

García-Gil S, Judd A (eds) (2007) Contrib 8th Int Conf Gas in Marine Sediments, Shallow Gas Group, 5-10 September 2005, Vigo, Spain. Geo-Mar Lett 27(2/4):71-302

Gramberg IS, Kontorovich AE (eds) (2002) Proc VI Int Conf Gas in marine sediments. Geologiya i Geofizika (Russian Geology and Geophysics) 43(7):585-711

Jørgensen NO (ed) (1994) Gas in marine sediments, 2nd Conference. Bull Geol Soc Denmark 41(1):3-109

Judd AG, Curzi PV (eds) (2002) Gas in marine sediments. Cont Shelf Res 22(16):2265-2442

Kalkowsky E (1908) Oolith und Stromatolith im norddeutschen Buntsandstein. Z Dtsch Geol Ges 60:68-125

Peckmann J, Gischler E, Oschmann W, Reitner J (2001) An Early Carboniferous seep community and hydrocarbon-derived carbonates from the Harz Mountains, Germany. Geology 29:271-274

van Weering TCE, Klaver GT, Prins RA (eds) (1997) Gas in marine sediments. Geology/geochemistry/microbiology. Mar Geol 137 $(1 / 2): 1-189$

Woodside JM, Garrison RE, Moore JC, Kvenvolden KA (eds) (2003) Proc 7th Int Conf Gas in Marine Sediments, 7-12 October 2002, Baku, Azerbaijan. Geo-Mar Lett 23(3/4):137-358

Woodside JM, Garrison RE, Moore JC, Kvenvolden KA (eds) (2004) Proc 7th Int Conf Gas in Marine Sediments and NATO Adv Res Worksh Seafloor Hydrocarbon Seeps, 7-12 October 2002, Baku, Azerbaijan -Part 2. Geo-Mar Lett 24(3):133-193 